Amasya Ilahiyat Dergisi - Amasya Theology Journal

ISSN 2667-7326 | e-ISSN 2667-6710

Haziran / June 2021, 16: 9-29

\title{
A Short Assessment of Gerson Cohen's View of Judaism and His Contributions to Conservative Judaism
}

\author{
İsmail BAŞARAN \\ Doç. Dr., Iğdır Üniversitesi, İlahiyat Fakültesi, \\ Dinler Tarihi Anabilim Dalı \\ Associate Professor, Iğdır University, Faculty of Theology, \\ Department of History of Religions \\ Iğdır, Turkey \\ ibasaran@hotmail.com \\ orcid.org/0000-0003-4408-0842
}

\section{Makale Bilgisi / Article Information}

Makale Türü / Article Types: Araştırma Makalesi / Research Article

Geliş Tarihi / Received: 9 Şubat / February 2021

Kabul Tarihi / Accepted: 8 Mayıs / May 2021

Yayın Tarihi / Published: 30 Haziran / June 2021

Yayin Sezonu / Pub. Date Season: Haziran / June

Sayı / Issue: 16 Sayfa / Pages: 9-29

Atıf / Cite as: Başaran, İsmail. "A Short Assessment of Gerson Cohen's View of Judaism and His Contributions to Conservative Judaism [Gerson Cohen'in Yahudiliğe Bakış Açısı ve Muhafazakâr Yahudiliğe Katkıları Üzerine Kısa Bir Değerlendirme]". Amasya Illahiyat Dergisi-Amasya Theology Journal 16 (June 2021): 9-29.

https://doi.org/10.18498/amailad.877555.

İntihal / Plagiarism: Bu makale, en az iki hakem tarafından incelendi ve intihal içermediği teyit edildi. / This article has been reviewed by at least two referees and scanned via a plagiarism software.

Copyright () Published by Amasya Üniversitesi, İlahiyat Fakültesi / Amasya University, Faculty of Theology, Amasya, 05100 Turkey. All rights reserved. https://dergipark.org.tr/amailad. 
10 I İ. BAŞARAN / Gerson Cohen'in Yahudiliğe Bakış Açısı ve Muhafazakâr Yahudiliğe Katkıları Üzerine Kısa Bir Değerlendirme

\section{A Short Assessment of Gerson Cohen's View of Judaism and His Contributions to Conservative Judaism}

\section{Abstract}

Cohen was born in New York to a Hebrew-speaking, moderately Jewish Orthodox and Zionist family of Russian origin. Cohen completed his undergraduate education in the Jewish Theological Seminary of America (JTSA) in 1943, which is the main center of Conservative Judaism, and simultaneously, in New York City College in 1944. Cohen also received his master's degree in JTSA and his rabbinic diploma in 1948. Cohen completed his doctorate at the University of Columbia in 1958.

Having studied Hebrew at a young age, Cohen has an important place in Conservative Judaism that is a branch of American Judaism. Cohen, who first started working as a librarian in JTSA (1950), started teaching Jewish History and Literature in the following years, and later continued as a professor. Cohen, who was the chancellor of JTSA between 1972-1986, is one of the best-known chancellors as he was the first chancellor to ordain a woman rabbi in Conservative Judaism. During his term, Cohen tried to make JTSA as a center of higher Jewish education for all Jews in the United States, especially for Jewish teachers, administrators and rabbis, and gave great importance to Torah studies, Zionism, Halakha and Hebrew learning and placed them in the center of Conservative Judaism.

With a historicist approach, Cohen saw today's Judaism as a continuation of historical Judaism. In his eyes, all Jewish religious education institutions in America, such as the JTS, were no different from the Yavneh academy in terms of their functions. He also regarded diversity as natural and was not afraid to use the term "Conservative Judaism" as a detached group. Cohen was telling his colleagues at the JTS that the Conservative movement should take pride in its achievements and thinking that the institutionalization of Jews in the American diaspora was vital for future generations.

Cohen's most striking idea was that he saw assimilation as a positive element for Jews. According to Cohen, it was justifiable that assimilation has a positive value when evaluated within the historical context of Judaism. For him, assimilation and cultural change should be seen as renewal, because these two factors stimulate the revival of Jewish thought life and contribute to the continuity of tradition. Although Cohen's idea was viewed by some as a creative idea, but mostly was criticized by Jewish circles. According to criticisms, Jews have 
suffered greatly in history due to assimilation, causing Jews not to survive for centuries. Especially in the Hellenistic and Greek periods, they lost their names, their language and even abandoned the sacred language of worship, which is Hebrew.

Cohen's expression of the "Jewish Group", additionally describing the Jews as a minority with the phrase; "Jews have always been a minority and will no doubt remain a minority" has alienated and isolated the Jews. While Cohen advocates dialogue between Jews in the diaspora (including other religions and other Jewish sects) with the external environment, on the other hand, seeing them as a "minority" and isolating them constitutes a great contradiction. Cohen also regards the support of Zionism and the State of Israel as a duty of every Jew in order to have "a healthy Israel". His Zionist family and environment, in which he grew up in his childhood, had a great influence on this idea. Indeed, Cohen's participation in the establishment of the Zionist organization, Merkaz, in Israel and the opening of JTS's branches and some schools in Israel, support his Zionist view. But this approach can be seen as a factor that weakens diaspora Judaism and can prevent it from acting independently.

Keywords: History of Religions, American Judaism, Moderate Orthodox, Conservative Judaism, Zionist.

\section{Gerson Cohen'in Yahudiliğe Bakış Açısı ve Muhafazakâr Yahudiliğe Katkıları Üzerine Kısa Bir Değerlendirme}

Öz

Cohen, New York'ta İbranice konuşan, 1lımlı Ortodoks, Rus kökenli Siyonist bir ailede dünyaya geldi. Cohen lisans eğitimini; 1943 yılında, Muhafazakâr Yahudiliğin ana merkezi olan Jewish Theological Seminary of America (JTSA) ve bununla paralel olarak New York City College'da (1944) tamamladi. Aynı zamanda Cohen, JTSA'da master derecesini ve 1948 yılında da rabinik diplomasını aldı. Cohen, doktorasını da Columbia Üniversitesi'nde 1958 yılında bitirdi.

Küçük yaşta İbranice eğitimi alan Cohen, Amerikan Yahudiliğinin bir şubesi olan Muhafazakâr Yahudilikte önemli bir yere sahip olmuştur. JTSA'da ilk önce kütüphaneci olarak göreve başlayan (1950) Cohen, daha sonraki yıllarda, Yahudi Tarihi ve Literatürü dersleri vermeye başlamış, daha sonra da profesör olarak görevine devam etmiştir. 1972-1986 yılları arasında JTSA'nın rektörlüğünü yapan Cohen, 1985 yılında Muhafazakâr Yahudilik içerisinde ilk defa kadın rabbi 
12 । İ. BAŞARAN / Gerson Cohen'in Yahudiliğe Bakış Açısı ve Muhafazakâr Yahudiliğe Katkıları Üzerine Kısa Bir Değerlendirme

atayan kişi olmasından dolayı en iyi bilinen rektörlerdendir. Cohen, rektörlük döneminde, başta Yahudi öğretmenler, idareciler ve rabbiler olmak üzere JTSA'yı, Amerika' daki tüm Yahudilerin eğitim merkezi olan bir üniversite haline getirmeye çalışmış, Tora Çalışmaları, Siyonizm, Halaka ve İbranice öğrenimi alanlarına büyük önem vermiş ve bunları Muhafazakâr Yahudiliğin merkezine yerleştirmiştir.

Cohen, tarihselci bir yaklaşımla, bugünkü Yahudiliği tarihten gelen Yahudiliğin bir devamı olarak görüyordu. Onun gözünde, JTS gibi Amerika' daki tüm Yahudi dini eğitim kurumları işlevleri itibariyle, Yavneh akademisinden farklı değildi. $\mathrm{O}$ aynı zamanda, çeşitliliği tabii karşılıyor ve müstakil bir grup olarak "Conservative Judaism" tabirini kullanmaktan çekinmiyordu. Cohen, JTS'teki meslektaşlarından, Muhafazakâr hareketin başarılarıyla iftihar etmeleri gerektiğini söylüyor ve Amerikan diasporasındaki Yahudilerin kurumsallaşmasının gelecek nesiller için hayatiyet arzettiğini düşünmekteydi. Cohen'in en çarpıcı fikri, asimilasyonu Yahudiler için bir pozitif unsur olarak görmesiydi. Cohen'e göre, aslında asimilasyonun Yahudiliğin tarihsel bağlamı içerisinde değerlendirildiğinde olumlu bir değerinin olduğuna hak vermekte bir sakınca yoktu. Ona göre, asimilasyon ve kültürel değişim, bir yenilenme olarak görülmelidir çünkü bu iki faktör, Yahudi düşünce hayatınının canlanmasını teşvik etmekte ve geleneğin devamlılığına katkıda bulunmaktadır. Cohen'in bu fikri bazıları tarafından yaratıcı bir fikir olarak görülse de çoğu Yahudi çevrelerce eleştirilmiştir. Eleştirilere göre, Yahudiler tarihte, asimilasyon dolayısıyla çok zarar görmüş ve asırlarca Yahudilerin ayakta kalamamasına sebebiyet vermiştir. Özellikle Helenistik ve Grek dönemlerinde Yahudiler, isimlerini, dillerini kaybetmişler ve kutsal ibadet dili olan İbranice' yi bile terketmişlerdir.

Cohen'in Yahudileri izole eden "Yahudi grubu" tabiri ile, yine Yahudileri bir azınlık olarak tarif eden; "Yahudiler daima azınlık olmuştur ve şüphesiz azınlık olarak kalacaktır" görüşü, Yahudileri yalnızlaştıran bir görüştür. Cohen, bir taraftan diasporada Yahudilerin (diğer dinler ve diğer Yahudi mezhepleri dahil) dış çevre ile diyaloğunu savunurken, diğer taraftan da Yahudileri bir "azınlık" olarak görüp onları toplumdan soyutlaması büyük bir çelişki oluşturmaktadır. Ayrıca Cohen, "sağlıklı bir İsrail" olabilmesi için Siyonizm ve İsrail Devleti'nin desteklenmesini her Yahudi'nin üzerine düşen bir görev olarak kabul etmektedir. Bu fikre sahip olmasında onun çocukluğunda yetiştiği Siyonist aile ve çevresinin büyük etkisi vardır. Nitekim, Cohen'in İsrail'de Merkaz adlı Siyonist organizasyonun kuruluşunda yer alması ve JTS'in İsrail'de şube ve bazı 
I. BAŞARAN / A Short Assessment of Gerson Cohen's View of Judaism and His Contributions to

Conservative Judaism | 13

okulları açması, onun Siyonist görüşünü desteklemektedir. Fakat bu yaklaşım, diaspora Yahudiliğini zayıflatan ve bağımsız hareket etmesini engelleyen bir faktör olarak görülebilir.

Anahtar Kelimeler: Dinler Tarihi, Amerikan Yahudiliği, Ilımlı Ortodoks, Muhafazakâr Yahudilik, Siyonist.

\section{Introduction}

Gerson David Cohen was born in New York in 1924. He attended Camp Massad ${ }^{1}$ that nurtured his devotion to the Jewish nation and Zionism and studied Hebrew and got education on other practices of Judaism when he was child. ${ }^{2}$

Cohen graduated from the City College of New York in 1944 with the Phi Beta Kappa ${ }^{3}$ special academics honors award, and later, continuing his education at JTS, ${ }^{4}$ in "The Teachers Institute and Rabbinical School" and he was awarded a bachelor's degree, then a master's degree followed by a rabbinic ordination (1948). Well-known professors such as Alexander

1 Massad Camp is a summer camp located in the Laurentian Mountains in Quebec, Canada, appealing to Jewish children aged 7-16, emphasizing Hebrew speaking and supporting Zionist understanding. Since its establishment in 1947, this camp has been providing educational services to around 400 Jewish children during the summer months. Camp Massad, "Our History” (Accessed: June 05, 2020).

2 Michael Panetz, "Cohen, Gerson D.", Encyclopedia Judaica 2nd Edition, ed. Michael Berenbaum - Fred Skolnik (Detroit: Macmillan Reference USA, 2007), 5/15.

3 It is recognized as the most prestigious academic honor award in America. This award, which has been given since 1776, has been conferred to many notable persons such as American Presidents and Foreign Ministers for their academic achievements during their university years. Phi Beta Kappa, “About” (Accessed: June 6, 2020).

4 It is an institution of higher religious education that is the backbone of the Conservative movement and trains rabbis for the movement. It is referred to as "JTS" in short. It was founded in 1886 in New York City of New York State in the United States of America and started education for the first time with eight students in 1887 under the leadership of Sabato Morais, Rabbi of the Mikveh Israel Synagogue. David Bridger, The New Jewish Encyclopedia (New York: Behrman House, 1962), 243. 
14 | İ. BAŞARAN / Gerson Cohen'in Yahudiliğe Bakış Açısı ve Muhafazakâr Yahudiliğge Katkıları Üzerine Kısa Bir Değerlendirme

Marx (d. 1953), ${ }^{5}$ Saul Lieberman (d. 1984) ${ }^{6}$ and Elias Bickerman (d. 1981) ${ }^{7}$ who taught at the JTS, played an important role in his upbringing. Cohen later started his doctorate study at Columbia University under the supervision of Professor Arthur Jeffery (d. 1959) ${ }^{8}$ and received the title of doctor $^{9}$ in the field of Semitic Languages in 1958 with his work on Abraham Ibn Daud's Sefer Ha-Qabbalah. ${ }^{10}$

5 He is a German-born Jewish historian. He came to New York to teach at JTS at a young age and also became the managing director of the JTS library. During his time, the JTS library had the world's largest collection of Jewish literature. He had a big part in Cohen's academic education. Geoffrey Wigoder, The New Standard Jewish Encyclopedia (New York: Facts On File. Inc., 1992), 633.

6 He is a Russian-born JTS Talmud professor and is often considered a right-wing member of the JTS due to his conservative ideas. He studied classical Jewish literature and philology at the Hebrew University in France and then in Palestine, came to New York in 1940 and became a Talmud professor at the JTS, and at the same time became the head of the Rabbinical School, the rabbinical department of the JTS. Geoffrey Wigoder, The Encyclopedia of Judaism (New York: Macmillan Publishing Company, 1989), 436-437.

7 He is an American Jewish historian and was born in Ukraine (Kishniev). He first taught at the University of Berlin, then immigrated to America and taught at JTS, Los Angeles University of Judaism and Columbia University. Bickerman has scientific studies on Ancient Jewish history, law and political history of the Hellenistic world. Dan Cohn Sherbok, Dictionary of Jewish Biography (New York: Oxford University Press, 2005), 35.

8 Jeffery (Australian origin) an American Orientalist and expert in Qur'anic studies. He was invited as an oriental teacher at the American University in Cairo, where he engaged in religious activities as a representative of the Methodist church. He deepened his studies on the science of qira'ah (science and methods of Qur'an recitation) in Egypt; He got acquainted with scholars such as Mûsâ Cârullah Bigi and Seyyid Nevvâr and, in his own words, learned from them what "a Christian could not learn alone". In 1929, he received a title of doctorate from the University of Edinburgh, England. In 1938, he moved to the United States and became head of the Near and Middle Eastern Languages Department of Columbia University (New York); he also taught the history of religions at the Union Theological Seminary, a Christian theological school. Rıza Kurtuluş, "Jeffery, Arthur", Türkiye Diyanet Vakfı İslâm Ansiklopedisi (Accessed: June 18, 2020).

9 Raymond P. Scheindlin, "Gerson D. Cohen (1924-1991)", Proceedings of the American Academy for Jewish Research 58 (1992), 15.

10 It is a book completed by Abraham Ibn Daud (Rabad) in 1161 about the development of the rabbinic Jewish tradition from Moses up to his time. Sefer Ha-Qabbalah, which means "The Book of Tradition", is an answer to the Karais who rejected rabbinic 
Because of his talent for languages and his familiarity with books, Cohen became JTS's library manager, first as an assistant and then successor to Alexander Marx, JTS's library director, and continued this duty between 1950-1957. His talent and charisma were discovered when he started teaching at JTS. Cohen has taught at JTS as Teaching Fellow (1953-1957), Lecturer (1957-1960), Visiting Assistant Professor (19611964), Visiting Professor (1964-1970), Professor of History (1970-1991), respectively. Although considered a historian, Cohen's first teaching post at JTS was in the Talmudic studies, which he continued to teach for many years, from both historian and philologist perspectives. Also in the first years of his career, he taught Syriac and Arabic as a lecturer at Columbia University, where he completed his doctorate. ${ }^{11}$

The recruitment of Cohen at JTS took place with Louis Finkelstein's ${ }^{12}$ invitation as a full-time professor of Jewish history and started to teach in 1970. Due to Finkelstein's resignation as a result of his increasing illness, he succeeded Finkelstein and became president of the faculty and chancellor of the Seminary (JTS) in 1972 and continued this duty from 1972 to 1986. Cohen's leadership at the JTS was crucial because he knew both classical Jewish religious education and modern secular education, otherwise it would not appeal to the children of thirdgeneration American Jews. Even at the handover ceremony, because of his features, Finkelstein compared Cohen to Solomon Schechter (d. 1915), ${ }^{13}$ who was the architect of JTS. Cohen saw JTS as the current

Judaism, and advocates for rabbinic Judaism. Harry Blumberg, "The Book of Tradition (Sefer ha-Kabbalah) by Abraham Ibn Daud", Speculum 44/4 (October 1969), 629-630.

11 Scheindlin, "Gerson D. Cohen (1924-1991)", 15.

12 Finkelstein, who was the chancellor of the JTS between 1940 and 1972, is considered among the most significant leaders of Conservative Judaism in the twentieth century. Finkelstein, first started his career at JTS in 1920 as a Talmud professor. After the death of the JTS Chancellor, Cryrus Adler, he was elected as Chancellor of JTS and got the title as the longest serving chancellor of the JTS with his thirty-two years in office. Pamela S. Nadell - Marc Lee Raphael, Conservative Judaism in America (New York: Greenwood Press, 1988), 84.

13 His period is considered to be one of the most important periods in Conservative Judaism. He was invited to America and became the chancellor of JTS. His term was turning point for the movement. Even Conservative Jews called the period up to Schechter's period as the foundation years of the JTS and his period as the years of 
16 | İ. BAŞARAN / Gerson Cohen'in Yahudiliğe Bakış Açısı ve Muhafazakâr Yahudiliğge Katkıları Üzerine Kısa Bir Değerlendirme

continuation and legacy of Jewish academies in Palestine and Babylon in the history. His appointment to this position meant that the JTS continued this tradition of raising its own leaders. At the same time, the appointment of a person of this quality was also vital for the American Jews to survive in the diaspora. ${ }^{14}$

\section{Cohen's View of Judaism}

Cohen offered a unifying and comprehensive formula for American Judaism. According to his understanding, all the Jewish accumulation that emerged in the historical process with its differences, it originated due to the rich history of Judaism. Cohen's holistic view of Judaism connects Jewish life and institutions of the age with those of his ancestors, demonstrating the continuity between New York and Yavneh, ${ }^{15}$ Tiberias, ${ }^{16}$ Pumbedita, ${ }^{17}$ Baghdad, Kordoba ${ }^{18}$ and Volozhin. ${ }^{19}$ His approach to the study of Judaism as a scholar was also an extension of this understanding because he saw Jewish religious education institutions in America like the

institutionalization. Some Conservative Jewish scholars divide the JTS as preSchechter and post-Schechter periods.

14 Nadell - Raphael, Conservative Judaism in America, 55.

15 It is the name of a town in Palestine. Just before the destruction of the Second Temple, a yeshiva was established here and became a Jewish educational center. According to the Talmud, the Romans allowed Rabbi Johanan ben Zakkai to continue the education of the yeshiva in Yavneh. After the destruction of the temple, it became the center of the Sanhedrin as well as the religious and intellectual center of Judaism. Bridger, The New Jewish Encyclopedia, 524.

16 This city is regarded as one of the four cities considered sacred by the Jews such as Jerusalem, Safed and Hebron. In the period of Tannaim and later periods, this city became an important Jewish educational center. Bridger, The New Jewish Encyclopedia, 481.

17 Pumbedita, a Babylonian city, is known to Jews for the establishment of a famous academy (yeshiva) by Judah ben Ezekiel in the middle of the 3rd century. This academy was moved to different cities by Ezekiel's successors and lastly survived in Baghdad. Wigoder, The New Standard Jewish Encyclopedia, 777.

18 Cordoba, an important Spanish city for Jews, became a famous settlement with the establishment of a Talmud academy (yeshiva) by Moses ben Enoch (972 AD). Wigoder, The New Standard Jewish Encyclopedia, 240-241.

19 It is a town in Lithuania. The Yeshiva, which served in this city between 1802-1892, provided religious education to Jewish youth from many countries. Wigoder, The New Standard Jewish Encyclopedia, 953. 
JTS as the continuation of historical religious education institutions such as the Yavneh academy in terms of their functions..$^{20}$

Cohen's understanding of Judaism also contained diversity. According to him, it was quite natural and common to have different opinions within Judaism, because in Jewish history, the Jewish community often did not agree on a single idea. As a reflection of this, Cohen was the first to use the term "Conservative Jew" in JTS's history during his term as chancellor, which had not been used before, in order not to present themselves as an ideological group and to avoid an ideological image, however, he saw no harm in using this term. On the other hand, Cohen, as a Jewish intellectual who supported Zionism, appreciated the fact that contemporary Jews were in fact in a historically unprecedented unification over the state of Israel. ${ }^{21}$

Based on the view that divisions within Judaism should be seen as richness, Cohen stated to his colleagues at JTS that they should take pride in the achievements of the Conservative movement and not to mind the fact of being excluded by Orthodox Jews. According to him, each group should improve itself and work to meet the needs of the Jewish community. Cohen argued that Conservative rabbis should not leave the leadership of American Judaism to the domination of Orthodox Jews, but should form independent administrations that oversee formal education for children, kosher, ${ }^{22}$ and $m i k w a h,{ }^{23}$ and raise their own circumcisers

20 Scheindlin, “Gerson D. Cohen (1924-1991)”, 17.

21 Nadell - Raphael, Conservative Judaism in America, 57.

22 Kosher, or Kashrut is a term that generally encompasses food products, religious objects, and people, appropriate to the religious needs of traditional Jews. The basic laws of Kashrut were explained in the Torah and later in the Talmud. Traditional Jews created special officers who oversee slaughter and similar kosher rules according to Jewish food laws. Bridger, The New Jewish Encyclopedia, 263-264.

23 This term, which is used in both forms as mikwah or mikvah, is a pool of 250-1000 liters of natural water such as rainwater or running water in Jewish homes for spiritual cleansing, similar to ghusl ablution in Islam. This pool must be carved out of stone or built in ground inground by digging. Jacob Neusner, The Routledge Dictionary of Judaism (London: Routledge, 2004), 90. 
18 I İ. BAŞARAN / Gerson Cohen'in Yahudiliğe Bakış Açısı ve Muhafazakâr Yahudiliğe Katkıları Üzerine Kısa Bir Değerlendirme

(mohalim) ${ }^{24}$ and butchers (shochatim). ${ }^{25}$ Cohen also called for more action in the social sphere between Conservative and Reformist movements. ${ }^{26}$

Cohen's speech titled "The Blessing of Assimilation in Jewish History" at the graduation ceremony of Hebrew Teachers College (Brookline, Massachusetts) ${ }^{27}$ in 1966, summarizes his view of Judaism. It is noteworthy that this speech of Cohen, which was later published as an article, ${ }^{28}$ coincided with the period when he was at the peak of his profession in terms of the maturity of his ideas as a historian and educator. Also around the same time, he was asked to lead the JTS, which was the main center of Conservative Judaism. Therefore, even though Cohen came from a family of Orthodox Jewish origin in such a period, the fact that the Jews in America were camped as; Reformist, Orthodox and Conservative and even fully adapted to American society was not an issue for him, on the contrary, he considered this picture in the diaspora as a continuation of Jewish history..$^{29}$

Cohen, who put forward his ideas with the title of "The Blessing of Assimilation," actually expertly reveals the connection between the past of Judaism and the present as a Jewish historian. When describing the connection of Judaism between its past and present, Cohen believes that the Torah and the rabbis who wrote important books such as Talmud, still

24 Its singular form is mohel. It is the Hebrew name given to the person who circumcised the child on the eighth day after the birth with the participation of the child's father and spiritual father (sandek / godfather) and the Jewish religious community (minyan). Bridger, The New Jewish Encyclopedia, 91-92.

25 Its singular form is shohet. It is the Hebrew name given to those who slaughter animals that are suitable to be kosher meat. According to the Talmudi law, ordinary people cannot slaughter any animals whose meat is eaten, including poultry, because they do not know the legal framework mentioned in the Talmud. Wigoder, The New Standard Jewish Encyclopedia, 861.

26 Nadell - Raphael, Conservative Judaism in America, 57.

27 Today it is called Hebrew College. Having a non-denominational understanding, Hebrew College has graduated 300,000 students so far and granted them title of rabbi. Hebrew College, "History” (Accessed: September 26, 2020).

28 See for the full text: Gerson D. Cohen, Jewish History and Jewish Destiny (New York: JTS Press, 1997), 145-156.

29 David B. Ruderman, "The Blessing of Gerson D. Cohen”, The Jewish Quarterly Review 106/4 (Fall 2016), 460. 
give the Jews a message today by speaking in some way. In this case, according to Cohen, there was no harm in accepting that assimilation has had a positive value when evaluated within the historical context of Judaism. From Philo's Alexandria to Saadia's Baghdad and Maimonides' Fustat, according to Cohen, diaspora Jewish communities not only survived progressively, but also adapted their own culture to the styles of their time. According to him, assimilation and cultural change should be seen as a renewal. Because these two factors encourage and stimulate the revival of Jewish thought of life and contribute to the continuity of the tradition. After all, this new combination that has emerged becomes more meaningful for future generations. ${ }^{30}$

In fact, it is possible to say that Cohen's idea of "assimilation", which points to integration and change, is based on the Positive Historical School, which is the historicist approach in Judaism. This school was pioneered by the German-born rabbi Zacharias Frankel (d. 1875). ${ }^{31}$ According to this school, change in the historical process is an inevitable phenomenon because the Jewish law (Halakha) ${ }^{32}$ has always changed according to the needs of the time in the historical process, and this process of change even continues today. Traditional Judaism has never been static for centuries, on the contrary, it has been the product of the historical development process by showing change and evolution. Traditional Judaism at all times should be taken as a basis. Change should be gradual and organic growth over time, not sudden and radical. Indeed, Judaism is the product of such a historical and centuries-long evolution. However, in this process

30 Ruderman, “The Blessing of Gerson D. Cohen”, 460.

31 Originally born in Prague, he was the founder of the Positive Historical School, which formed the philosophical foundations of Conservative Judaism. For him, it is the Jewish community itself that determines Jewish practices in each generation. Sara E. Karesh - Mitchell M. Hurvitz, Encyclopedia of Judaism, ed. J. Gordon Melton (New York: Facts On File, Inc., 2006), 162-163.

32 They are the rules, criteria and regulations that dominate every period of Jewish life and that concern the social, political, internal, economic and especially religious life of the person. This term is also used to refer to sections in the Rabbani literature related to legal issues. Halakha's purpose is to follow God's way. Harry A. Cohen, A Basic Jewish Encyclopedia (Hartford USA: Hartmore House, 1965), 104-105. 
20 | İ. BAŞARAN / Gerson Cohen'in Yahudiliğe Bakış Açısı ve Muhafazakâr Yahudiliğe Katkıları Üzerine Kısa Bir Değerlendirme

of change, the essence of Judaism and the binding feature of Halakha must be preserved. ${ }^{33}$

Another view of Frankel is related to the Scriptures. According to him, the Scriptures should be interpreted. Because in the past, Mishnah and Talmud scholars have not only taken the literal meaning of the Scriptures, but also added their own interpretations. Their practices constituted a principle for the necessity of change in Judaism. For him, this was a great achievement for Judaism. Since Judaism is not static, but a religion of action and with the feature of being applicable to practical life, it should be regarded as the property of every Jew. ${ }^{34}$

It is possible to say that Cohen's idea of 'The Blessing of Assimilation', which points to excessive compliance and is considered dangerous by some Jewish circles, became more moderate and cautious after serving as the chancellor of JTS, due to the pressure and influence of the Orthodox professors, who were the right wing of JTS. These innovative or reformist ideas, which carry the historicist approach even further, could not be realized in a single moment, as in the example of the "ordination of women as rabbis", which was realized as a result of discussions spread out to four years.

The Conservative movement has always emphasized that it is a "positive-historical" movement, however, most of the time it defended the "historical" side of the movement, namely the traditional side, and the "positive" side, which represents change, as in the issue of the role of women (getting certified by the JTS as rabbi) it had difficulties in implementing it and spread the change over time. Because the change according to the segment (academic staff and decision makers) of the JTS who received classical Jewish religious education, it represented a break from tradition and harbored doubts. Hence, tradition was mostly used to defend the status quo. In Conservative Judaism, when debates about the status of women were being held with also the influence of feminist

33 Robert Gordis, Conservative Judaism: An American Philosophy (New York: Behrman House, 1945), 16-17.

34 Zacharias Frankel, "On Changes in Judaism", Tradition and Change, ed. Mordecai Waxman (New York: United Synagogue of Conservative Judaism, 1958), 48. 
movements such as Ezrat Nashim, ${ }^{35}$ it was considered to be an extremely "liberal" situation to allow women to have rights such as equal access to rituals and becoming rabbis. For this reason, opponents of the women's issue believed that such a movement would undermine the role of Halakha in the Conservative movement and would eliminate the distinction between the Reform and the Conservative movement. ${ }^{36}$ This is why the process of change of the Conservative movement in many issues concerning Halakha took place gradually and the liberal wing mostly dominated, albeit late.

On the other hand, Cohen's views on Judaism also led to reactions and criticism. One of the Jewish scholars who recently criticized Cohen's idea of "The Blessing of Assimilation" was Arnold Eisen. Eisen is a prominent scholar of American Judaism and served as the chancellor of the JTS from 2007 to $2020 .{ }^{37}$

Eisen, who is Jewish Thought professor and former chancellor of JTS, in his article titled "The Case for" Assimilation" and Diaspora"; noted that Cohen's idea primarily might be clever but it is provocative too. Because assimilation has been very costly to the Jews in the history contrary to Cohen's claim. Put forward by Cohen; "as in the Hellenistic and Greek periods, the Jews took their names from the nations that they lived with and lived like those societies culturally, they spoke their language and worshiped with languages other than Hebrew", although Eisen is accepting this reality, but he also reminds the fact that Jews could not survive and develop in the diaspora for centuries in some periods as a result of assimilation. ${ }^{38}$

35 This organization, which means "Helping Women" in Hebrew, is a feminist Jewish organization established in New York in 1971 within the Conservative movement to defend the equality of men and women on issues such as women's admission to education at the JTS and their subsequent ordination as rabbis. Jewish Women's Archive, "Ezrat Nashim" (Accessed: September 29, 2020).

36 Dvora Weisberg - Dvora E. Weisberg, "Jam Every Other Day: Reflections on Twenty Years as a Conservative Jewish Feminist", Shofar 16/4 (Summer 1998), 58.

37 Arnold Eisen, "The Case for "Assimilation" and Diaspora", Jewish Quarterly Review, 106/4 (Fall 2016), 450.

38 Eisen, "The Case for "Assimilation" and Diaspora", 450 - 451. 
22 | İ. BAŞARAN / Gerson Cohen'in Yahudiliğe Bakış Açısı ve Muhafazakâr Yahudiliğe Katkıları Üzerine Kısa Bir Değerlendirme

Eisen also points out to a confession of Cohen. According to Eisen, Cohen essentially admits that assimilation is a threat by using the term "the Jewish group". Because fear of assimilation has always isolated Jews as "the Jewish group" and exposed them in some way to the threat of extinction contrary to the idea of "the Blesssing of Assimilation". Indeed, the fact that he said, "The Jews have always been a minority, and they will undoubtedly remain a minority" is a sign of this confession. According to Eisen, Cohen's idea that "Jews have always been a minority", may not appear to be a controversial issue at first glance, but it gives rise to the thought of Zionism and points to the Zionist idea of the creation of the State of Israel. Because, according to the Zionist idea, it was claimed that the diaspora life (galut) of Jews would end with the establishment of a Jewish State. ${ }^{39}$ As a result, Cohen admits that every Jew has a duty to the Land of Israel and even the State of Israel. According to him, this is necessary for a "healthy Israel" otherwise, Israel (Jews) cannot be powerful. ${ }^{40}$

Indeed, Cohen advocated the strengthening of Conservative Judaism as a branch of American Judaism, in other words, the empowerment of Jews through institutionalization in the diaspora. In this regard, Cohen made great efforts. Hence, Cohen's advocacy of the strengthening of diaspora Judaism on the one hand, and on the other hand, to see the Jews as a "Jewish group" by isolating them, constitutes contradiction. Besides, his support for Zionism can be seen as a factor that weakens diaspora Judaism in some way and reduces focus on it as well. Consequently, Cohen's view of the Jews as a separate group and his support for Zionism could pose an obstacle to American Jews acting independently and establishing their own Jewish culture.

On the other hand, JTS professor Neil Gillman who took a different approach to Cohen's view. Gillman, who has been a professor of Jewish philosophy at JTS for many years, stated that the idea of "The Blessing of Assimilation" defended by Cohen is a synthesis. In fact, the essence of this idea is to assimilate the best from outside or from non-Jewish culture into the fabric of Judaism. Therefore, when this is the case, Judaism has always

39 Eisen, "The Case for "Assimilation" and Diaspora", 451.

40 Eisen, "The Case for "Assimilation" and Diaspora", 453. 
been able to be most creative and most vital. This synthesis reflects "the spirit of Cordova". The era of Muslim rule (known as Al-Andalus) in Spain (8th-11th century) was considered the "Golden Age" for Spanish Jewry. At that time, Spanish Jewry were an open society and the Islamic culture influenced them in many areas. For instance, Arabic was a shared language and because of that, the Jewish language of worship had become Arabic. Thus, this society was able to create a great synthesis of two great (Jewish and Muslim) cultures and thanks to this synthesis Judaism has survived for centuries. ${ }^{41}$

\section{Cohen's Contributions to Conservative Judaism as a Branch of American Judaism}

As a Jewish intellectual, Cohen believed that diaspora had the central role for the evolution of Judaism and Jewish culture. According to him, Conservative Judaism had an important role in the American Jewish diaspora and was the movement that reconciled tradition and modernity. At the same time, the existence of Conservative Judaism showed the diversity in Jewish history as before. Based on this idea, he fully supported this understanding and made great efforts to strengthen it. ${ }^{42}$

It should be stated that Cohen continued and further developed the educational policies of his predecessor, Louis Finkelstein, that the JTS should play a greater role in Jewish studies worldwide. Cohen's contributions to American Judaism can be summarized as follows, in the context of the JTS:43

First of all, to mention Cohen's most important contribution, JTS became a leading center for Judaism Studies during his period. Thanks to Cohen, JTS became an important scientific center both in America and in the world. In addition, the library, which had been damaged by the fire in the 1960s, was rebuilt.

Secondly, Cohen placed emphasis on relations with members of other religions and developed interfaith relations with Protestant groups

41 Neil Gillman, Conservative Judaism: The New Century (New Jersey: Behrman House, 1993), 140.

42 Paula E. Hyman, "The Unfinished Symphony The Gerson Cohen Years", Tradition Renewed: A History of The Jewish Theological Seminary of America, ed. J. Wertheimer (New York: The Jewish Theological Seminary of America, 1997), 1/250.

43 Panetz, “Cohen, Gerson D.", 5/16. 
24 | İ. BAŞARAN / Gerson Cohen'in Yahudiliğe Bakış Açısı ve Muhafazakâr Yahudiliğe Katkıları Üzerine Kısa Bir Değerlendirme

that constitute the majority of American society. In relation to this, he continued "The Institute for Religious and Social Studies", which his predecessor Finkelstein established within the University. In addition to interfaith relationships, Cohen also conducted academic cooperation and student exchange programs with these groups. The most important example in this regard was "The Union Theological Seminary". Academic cooperation was established with this school, which was one of the most important Christian (Protestant) Theology schools of New York.

Cohen's third major contribution was the administrative renewal of the JTS and the creation of an independent graduate school in Jewish Studies. Cohen changed the program's name "The Institute for Advanced Studies in the Humanities" with the name "The Graduate School of the Jewish Theological Seminary" and opened this new program to all Jewish students without regard to sectarian distinction (Reformist, Orthodox and Conservative). This program became the most respected program in the diaspora for graduate students. At the same time, at the end of the twentieth century, it had been instrumental in the training of academicians who will teach in the field of Jewish Studies at American universities. This program would play a great role in the upbringing of future Jewish generations and in surviving as Jews in the diaspora.

Four years after the program began, the program was further expanded and became the largest division of the JTS in terms of students and curriculum, with twenty-seven PhD's and one hundred and fifty-five masters students. Cohen was pleased that these students from different backgrounds and Jewish sects participated in the program and stated that it was noteworthy for future rabbis to get an education together without being labeled in any way. ${ }^{44}$

Fourthly, in addition to all these services mentioned above, Cohen has made a great contribution to the advancement of Conservative Judaism ${ }^{45}$ in Israel. Cohen thought that the JTS would make a substantial contribution to Jewish religious life in Israel. For this purpose, Cohen enabled Conservative rabbis to be in Israel to gain both religious and educational experience. Because in this way, Conservative rabbis would

44 Hyman, "The Unfinished Symphony The Gerson Cohen Years", 242-243.

45 The Hebrew term Masorti (traditional) is used for Conservative Judaism in Israel. 
serve both the Conservative movement and world Judaism better and better equipped. Cohen increased the credibility of the school by opening a JTS campus in Israel, called Neve Schechter and Midreshet Yerushalayim, a Conservative yeshiva program. In addition, for JTS rabbinic students who would be studying in Israel for a certain period of time, they had the chance to have a residence permit from the Israeli Government. Cohen also established Beit Hamidrash Lelimudei Hayahadut as an independent Conservative rabbinic school in Israel in $1984 .{ }^{46}$

Because of all these activities carried out in Israel, Cohen's aim was both to enable JTS students to concentrate their studies in Israel as Holy Land and to increase the visibility of Conservative Judaism in there. ${ }^{47}$ Cohen also took steps to make the presence of Conservative Jews visible in Israel and legalize Conservative Judaism because it was not a wellknown movement in Israel. In relation to this, in 1978 he participated and took part in the creation of Merkaz, ${ }^{48}$ which he described as a Zionist fragment within the Conservative movement. ${ }^{49}$

Lastly, in Conservative Judaism, what makes Cohen different and remarkable was "the ordination of women as rabbis". ${ }^{50}$ Among the most heated debates of the Cohen era was whether women could be ordained Conservative rabbis because this issue was a complex issue with regard to the religious practices of Judaism. ${ }^{51}$

Robert Gordis, who put forward the ideology of the Conservative movement by publishing his work Conservative Judaism: An American Philosophy in 1945 and clarified this ideology by heading the "Emet Ve -

46 Panetz, "Cohen, Gerson D.", 5/16.

47 Hyman, "The Unfinished Symphony The Gerson Cohen Years", 251.

48 It still operates today as a Zionist organization of Conservative Judaism. Merkaz USA, (Accessed: April 26, 2021).

49 Hyman, "The Unfinished Symphony The Gerson Cohen Years", 253.

50 The issue of women not being ordained as rabbis is a complicated issue related to Halakha. According to Judith Hauptman, the first Talmud professor of the JTS, Talmud writers and commentators have always been male. They always exhibited their views from this point of view. Therefore, it was not possible until recently (1980's) that women were banned from Talmud studies and therefore, they could not have the opportunity to be ordained as rabbis. Judith Hauptman, Rereading the Rabbis A Woman's Voice (Colorado: Westview Press, 1998), 1.

51 Gillman, Conservative Judaism: The New Century, 139. 
26 | İ. BAŞARAN / Gerson Cohen'in Yahudiliğe Bakış Açısı ve Muhafazakâr Yahudiliğe Katkıları Üzerine Kısa Bir Değerlendirme

Amunah"52 work in the following years (1980s), points to this complex issue. According to him, there are two different views in the Talmud: teaching Torah to women and banning them from learning it, and these views contradict each other because while one is in favor of women, the other is against them. Therefore, it cannot be deduced from this text that women cannot be ordained as rabbis. In conclusion, it should be moved from the fact that Halakha did not prohibit the ordination of women as rabbis and this issue should be decided by discussing on an innovative ground, not on an imaginary ground.$^{53}$

When the issue of female rabbis first came up at JTS and was rejected by the majority in 1977, Cohen strongly advocated the ordination of women as rabbis and saw no risk or inconvenience to the Conservative movement in this reform proposal. If the Conservative movement did not carry out this reform, in other words, it could not ordain women as rabbis, it could risk its position because it could not meet the expectations of the American Jewish community. But he was hopeful that the Rabbinical Assembly (RA), ${ }^{54}$ which is authorized to make decisions on this issue, would make a positive decision in this direction, as women were also receiving education in other rabbi-training schools. Although Cohen could not convince the JTS academics in the first voting held in 1979 (that was personal defeat), ${ }^{55}$ four years later, the movement's pressure on the ordination of women rabbis was influential and the JTS academics (as a majority) had to take this decision, and Cohen changed the JTS's legislation so that JTS had begun to accept women as well. ${ }^{56}$

52 See. Emet ve Emunah: Statement of Principles of Conservative Judaism (New York: The Jewish Theological Seminary of America, The Rabbinical Assembly, The United Synagogue of America, 1988)

53 Robert Gordis, Understanding Conservative Judaism (New York: The Rabbinical Assembly, 1978), 13-14.

54 It is one of the three most important institutions of Conservative Judaism. It was founded in 1901 by the pioneers who formed the JTS. It is an international association of conservative rabbis. Gillman, Conservative Judaism: The New Century, 65.

55 Gillman, Conservative Judaism: The New Century, 140.

56 Panetz, "Cohen, Gerson D.", 5/16. 


\section{Conclusion}

Consequently, Cohen's significance and leadership is directly related to the period in which he came to prominence. Because, in the 1970s, Conservative Jews approximately neared $50 \%$ of the total Jewish population in the U.S.A. and ranked first numerically. So Cohen, who was the chancellor of the JTS in such a period, saw himself not only as the leader of this school but also as the leader of the movement, and was aware that he had a considerable responsibility for American Jews. Thinking that the JTS should be the flagship of the movement, Cohen argued that this higher education institution should be revised to meet the needs of third generation American Jews and made many innovations in this regard.

Cohen stated that the third generation Jews in America have now become American by being integrated into American society and therefore, as Jews in America, they must create a new culture of their own. Saying that the JTS and the Conservative movement are at a turning point in realizing this vision, Cohen insistently emphasized that, first, JTS must maintain its superior position as an academic Jewish educational institution, and then the Conservative movement must also benefit from the innovations of modernity by enabling the development of Jewish culture through Halakha.

On the other hand, due to the fact that he comes from a Zionist family of Russian origin, Cohen perceived Zionism as a positive force in Jewish history and thought that it should be supported. Based on this idea, he increased the effectiveness of the Conservative movement in Israel by opening a branch of the JTS and a yeshiva in Israel. Known for his radical and controversial views, such as seeing "Assimilation as a Blessing for the Jews", Cohen will be remembered most in the history of American Judaism for his radical change (big reform) in the ordination of women as rabbis.

\section{Bibliography}

Blumberg, Harry. "The Book of Tradition (Sefer ha-Kabbalah) by Abraham Ibn Daud". Speculum 44/4 (October 1969), 629-630. https://doi.org/10.2307/2850394 
28 | İ. BAŞARAN / Gerson Cohen'in Yahudiliğe Bakış Açısı ve Muhafazakâr Yahudiliğe Katkıları Üzerine Kısa Bir Değerlendirme

Bridger, David. The New Jewish Encyclopedia. New York: Behrman House, 1962.

Camp Massad. Accessed June 5, 2020. https://campmassad.org/aboutcamp/our-history.html

Cohen, Gerson D. Jewish History and Jewish Destiny. New York: JTS Press, 1997.

Cohen, Harry A. A Basic Jewish Encyclopedia. Hartford, USA: Hartmore House, 1965.

Cohn-Sherbok, Dan. Dictionary of Jewish Biography. New York: Oxford University Press, 2005.

Eisen, Arnold. "The Case for "Assimilation" and Diaspora". Jewish Quarterly Review 106/4 (Fall 2016), 450-458.

Emet ve Emunah: Statement of Principles of Conservative Judaism. New York: The Jewish Theological Seminary of America, The Rabbinical Assembly, The United Synagogue of America, 1988.

Frankel, Zacharias. "On Changes in Judaism". Tradition and Change. (ed.) Mordecai Waxman. 43-50. New York: United Synagogue of Conservative Judaism, 1958.

Gillman, Neil. Conservative Judaism: The New Century. New Jersey: Behrman House, 1993.

Gordis, Robert. Understanding Conservative Judaism. New York: The Rabbinical Assembly, 1978.

Gordis, Robert. Conservative Judaism: An American Philosophy. New York: Behrman House, 1945.

Hauptman, Judith. Rereading the Rabbis A Woman's Voice. Colorado: Westview Press, 1998.

Hebrew College. Accessed September 26, 2020. https://hebrewcollege.edu/about/history/

Hyman, Paula E. "The Unfinished Symphony The Gerson Cohen Years", Tradition Renewed: A History of The Jewish Theological Seminary of America, ed. J. Wertheimer. 1/233-269. New York: The Jewish Theological Seminary of America, 1997.

Jewish Women's Archive. Accessed September 29, 2020. https://jwa.org/node/12146

Karesh, Sara E. - Hurvitz, Mitchell M. Encyclopedia of Judaism. (ed.) J. Gordon Melton, New York: Facts On File Inc., 2006. 
Kurtuluş, Rıza. "Jeffery, Arthur". Türkiye Diyanet Vakfı İslâm Ansiklopedisi. Accessed: June 18, 2020. https://islamansiklopedisi.org.tr/jefferyarthur

Merkaz USA. Accessed: April 26, 2021. https://www.mercazusa.org/

Nadell, Pamela S. - Raphael, Marc Lee. Conservative Judaism in America. New York: Greenwood Press, 1988.

Neusner, Jacob. The Routledge Dictionary of Judaism. London: Routledge, 2004.

Panetz, Michael. “Cohen, Gerson D.". Encyclopedia Judaica (2nd Edition). ed. Michael Berenbaum - Fred Skolnik. 5/15-16. Detroit: Macmillan Reference USA, 2007.

Phi Beta Kappa. Accessed June 6, 2020. https://www.pbk.org/About

Ruderman, David B. "The Blessing of Gerson D. Cohen". The Jewish Quarterly Review 106/4 (Fall 2016), 459-464. https://doi.org/10.1353/jqr.2016.0034

Scheindlin, Raymond P. "Gerson D. Cohen (1924-1991)". Proceedings of the American Academy for Jewish Research 58 (1992), 15-18.

Weisberg, Dvora - Weisberg, Dvora E. “Jam Every Other Day: Reflections on Twenty Years as a Conservative Jewish Feminist". Shofar 16/4 (Summer 1998), 51-61. http://dx.doi.org/10.1353/sho.1998.0031

Wigoder, Geoffrey. The New Standard Jewish Encyclopedia. New York: Facts On File Inc., 1992.

Wigoder, Geoffrey. The Encyclopedia of Judaism. New York: Macmillan Publishing Company, 1989. 